\title{
EDTA 法による食品中マグネシウム含有量の再吟味
}

The Scrutiny of Magnesium contents in Food by the EDTA-Method

(昭和 30 年 6 月 9 日受理)

\author{
神谷保男山田新太郎 \\ (Yasuo Kamitani) (Shintaro Yamada)
}

（本論交の要旨は第 9 回栄㭽・食鋉学会に於て報告した）

\section{Iはしがき}

食品中のマグネシウム定量法として従来から用いられ て来た方法としては，ビロ燐酸マグネシウムとして秤る 重量法, オキシン臭素酸カリによる容量法, チアゾール イェローに上る比色法, マダネソンによる比色法等があ るが，永原氏はこれ等の諸法の中で精度の点からは重量 法が最良であるが，操作か複雑であり多大の時間を要寸 ること等から，簡単で迅速な方法が考えられるべきであ ると述べておる(1。

所が最近 Ethylendiamin Tetraacetic Acid の Disodium Salt (EDTA) と重金属及び $\mathrm{Mg}, \mathrm{Ca}$ とか 定量的に結合することが発見され(2)，これ等の定量用試 薬として用いられつつある。夾雑物の少い場合，例えば 上水等については EDTA 法は正確で迅速に定量出来て 優れた定量法と云われている。併し本法をひとたび食品 分析に適用しよ5とする場合には，EDTA の特性即ち 種々のイオンにひろく結合する性質のために, 種々の共 存イオンがその定量を妨害しこれれでの動植物性食品

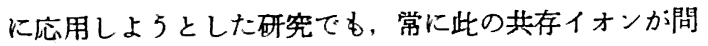
題になり難点とされていた。そこで我々はこの点に留意

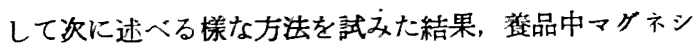
ウムの定量に充分応用出来ると思われる結果を得たの で,これを用いて主要食品二十余種類中のマグネシウム 含有量を定量した。

\section{II 実娩方法}

\section{（1）原法の検討と改变}

（a）この定量法に使用寸る指示薬の Ca による発色 が Mg による場合より不明瞭であり, 共存イオンが加 わると特にこの傾向か强いよ5なので，測定しようとす る試料液から Ca を除いた後 $\mathrm{Mg}$ のみを定量すること にした。このため $\mathrm{Mg}, \mathrm{Ca}$ を同時に測定出来るとい5 EDTA 法の一つの特徵が減ずるわけであるか，Willson ${ }^{(3)}$ もこの方法を推桨している。

（b）定睹の際の滴定法として，初めに Mg で呈色す る指示薬 Eriochrome Black T (EBT) を加えて赤く
呈色させ，これを EDTA 溶液で青くなる迄滴定する值 接商定法と，测定しょうとする $\mathrm{Mg}$ と結合してなお過 剩となる一定遗の EDTA 溶液を加之，指示蔡を加えて 㙁化マグネシウム溶液で青から赤になる迄滴定する間接

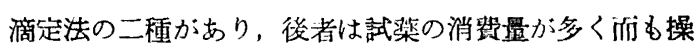
作がやや面倒であるが，精度は直接滴定法より多少すぐ れて居り，Cu 等の妨害イオンの影響も幾分少く(4)，ま た㭘液中に $\mathrm{Mg}$ と正燐酸か;共存する場台アンモニヤで アルカリ性にすると $\mathrm{NH}_{4} \mathrm{MgPO}_{4}$ の沈浅が生ずるが, EDTA を加えてからアルリカ性にするとこの沈汼は生 じない等の長所があるため間接滴定法によることにし た。

（c）間接滴定法によつた場台に滴定の終点は青色が 葡萄酒梯赤色に変つた所を㹉ることになつているが, 我 我の経耠では青色が僅に赫味を带びた所を終点とする方 が正確に読めるように思われたので両者の読みを繰返し て行つて㭘討してみた。即ち同一試料について赤くなり 始めるときの滴定值と赤くなり切つたときの滴定值を読 むことを夫々 3 回ずつ 23 個の試料について繰り返した。 その結果を推計学的に処理して見ると, 変色の開始時で 見たときと变色の終了時で見たときと，分散の值に明か に有意な美が認められる。即ち変色の開始時で㜔んだ方 が滴定值か塮つていた。このことから滴定の終点は青色 が僅に赤跦を带びた所を探用することにした。

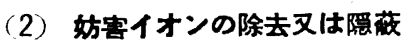

動植物性食品中に含まれるイオンの中で EDTA と結 合するすのとしては, $\mathrm{Mg}, \mathrm{Ca}, \mathrm{Fe}, \mathrm{Cu}, \mathrm{Mn}, \mathrm{Al}, \mathrm{Ni}$, $\mathrm{Co}, \mathrm{Cd}, \mathrm{Zn}$ 等があると思われるので滴定前に於けるこ れ等のイオンの除去又は隐醇は次の上5な方法で行つた が, Ca については予蓝酸 $\mathrm{Ca}$ として除いてあるので ここでは問題とはならない。

Diehl, Goetz ${ }^{(5)}$ は種々の妨等イオンの隐酸に KCN を 用いてその有效性を検べた笑験に於て，Al に対しては KCN が無効であることを述べて扣る。柳沢氏(6)が妨害 イオンの各々についてその竝害値の大小を検討した㿤隔 によれば，Al はそれ等の中で最大の妨害値を示してお 
る。また過去に行われた所の食品中 $\mathrm{Al}$ 含有量の成綪(7) によると相当多量含まれていることになつている。これ 等の事から Al の妨慧を除くことは重要なことと考えら れる。そこでそれには三何の金属と結台して沘轻させる 所の安息香酸(\$)を用いて除去することにした。

食品中に含まれている Fe には二洒のすのと三㑜のも のとがあるが，食品を酸化して試料液にする幍程に於て $\mathrm{Fe}^{++}$はすべて $\mathrm{F}^{+++}$になるから， $\mathrm{Fe}$ も寸へてての实 息香酸によつて沈殿除去されることになる。侗目残存し てもそれは KCN で隐諓されるから妨篦は全く除かれる わけである。柳沢氏は EDTA 定量法は $\mathrm{Fe}, \mathrm{Mn}, \mathrm{CO}$ 等が多量に含ま机ている食品ではそ机等の妨忠により $\mathrm{Mg}$ 量は高值を示寸と述へて扰る゙が，その览念は $\mathrm{Fe}$ を安息香酸により除くことによつて軽減されることにな $\eta, \mathrm{Ni}, \mathrm{Mn}, \mathrm{Co}$ に対して KCN はそれだけ有效に作用 寸ることになるわけである。

等 1 表

各妨害物空策独添加時の影㪇

(小数点 3 位以下四唅五入)

\begin{tabular}{|c|c|c|c|}
\hline & 添加量( $\mathrm{mg}$ ) & 実測値 $(\mathrm{mg})$ & $\begin{array}{c}\text { 实測値と理論 } \\
\text { 做との差 } \\
\text { 到 }\end{array}$ \\
\hline \multirow{3}{*}{$\mathrm{Mg}^{++}$} & 0 & 1.00 & 0 \\
\hline & 0 & 1.01 & +0.01 \\
\hline & 0 & 1.00 & 0 \\
\hline \multirow{3}{*}{$\mathrm{Fe}^{+++}$} & 1.00 & 1.00 & 0 \\
\hline & 2.00 & 1.00 & 0 \\
\hline & 4.00 & 1.01 & +0.01 \\
\hline \multirow{3}{*}{$\mathrm{Al}^{+++}$} & 1.00 & 1.00 & 0 \\
\hline & 2.00 & 1.00 & 0 \\
\hline & 4.00 & 1.02 & +0.02 \\
\hline \multirow{3}{*}{$\mathrm{Mg}^{++}$} & 0 & 0.50 & 0 \\
\hline & 0 & 0.50 & 0 \\
\hline & 0 & 0.50 & 0 \\
\hline \multirow{3}{*}{$\mathrm{Ca}^{++}$} & 1.00 & 0.50 & 0 \\
\hline & 2.50 & 0.50 & 0 \\
\hline & 5.00 & 0.50 & -0.01 \\
\hline \multirow{3}{*}{$\mathrm{Mg}^{++}$} & 0 & 0.25 & 0 \\
\hline & 0 & 0.25 & 0 \\
\hline & 0 & 0.25 & 0 \\
\hline \multirow{3}{*}{$\mathrm{Mn}^{++}$} & 0.25 & 0.25 & 0 \\
\hline & 0.50 & 0.25 & $\quad \cdots 0.01$ \\
\hline & $0.75^{\prime}$ & 0.27 & +0.02 \\
\hline \multirow{3}{*}{$\mathrm{Cu}^{++}$} & 0.25 & 0.25 & 0 \\
\hline & 0.50 & 0.25 & 0 \\
\hline & 0.75 & 0.25 & +0.01 \\
\hline
\end{tabular}

そこで $\mathrm{Mg} \mathrm{SO} 47 \mathrm{H}_{2} \mathrm{O}$ を $\mathrm{Mg}$ 橙準液としてこれに主 な妨寒イオン $\mathrm{Fe}, \mathrm{Al}, \mathrm{Ca}, \mathrm{Mn}, \mathrm{Cu}$ を夫夕階段的に添 加した液について，上記の方法により曖放又は除去を行 つてその影響を梌颜した結果，第1表のようになつた。 即ち $\mathrm{Mg}$ は $1 \mathrm{mg}, 0.5 \mathrm{mg}, 0.25 \mathrm{mg}$ の备澧度に於ては此

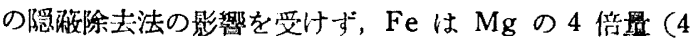
$\mathrm{mg}$ )で 1\%の䛊差を生じ, Al は $\mathrm{Mg}$ の 4 倍量 (4mg) で $2 \%, \mathrm{Ca}$ は 10 倍量 $(5 \mathrm{mg})$ で $1 \%$ の誤美を認めた。

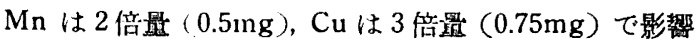
を受けているが，徒来の成績を(7)(9) 見ると食品中の $\mathrm{Mn}$ 照， $\mathrm{Cu}$ 量か $\mathrm{Mg}$ 含有量の 2 倍乃至 3 倍に達することは 榒めて稀であり，此等に関する過去の報告を信用するな らこの辺りの影響は支障がいいのと考えられる。

\section{（3）改变法操作の総括}

本定量法を行らに当り次の試葉を調製した。

(試 薬)(10)

1 EDTA : EDTA $2 \mathrm{~g}$ を $1000 \mathrm{ml}$ の水に溶かし, 反 応促進のため約 $0.05 \mathrm{~g}$ の $\mathrm{MgCl}_{2}$ を加える。

口 $\mathrm{MgCl}_{2}$ (滴定用): $\mathrm{MgCl}_{2} 6 \mathrm{H}_{2} \mathrm{O}$ の約 $6 \sim 7 \mathrm{~g}$ を $1000 \mathrm{ml}$ の水に溶力す。

八指示葉: Eriochrome Black T (EBT) $0.5 \mathrm{~g}$, 塩 酸ヒドロキシルアミン $4.5 \mathrm{~g}$ をメチールアルコール $100 \mathrm{cc}$ に溶解する。

二椤徆液: $\mathrm{NH}_{4} \mathrm{Cl}$ 約 $67.5 \mathrm{~g}$ を $28 \%$ アンモ二ヤ水 570cc に溶解し，水を加えて $1000 \mathrm{cc}$ とする。

木 基华溶液：塩化第二水銀 $1 \mathrm{~g}$ を正確に化学天秤に て秤取し，蒸溜水で正確に $1000 \mathrm{cc}$ とする。使用の 際は適当な漲度まで稀釈して用いる。

一 安息香酸：水に溶かして 5\% 浴液にする。

卜 炧和苳酸安門

チメチールレッド

リ. $1: 4$ 塩酸淮液

又 $1: 4$ アンモ二ヤ水

儿 $1: 4$ 醋酸水

э $20.0 \mathrm{KCN}$ 涳液

(作)

艺ず一定量の試料をるつぼに入れて灰化し，1:4 の㙁 酸溶液に溶かしてビーカに移し，沸㙁酸 $5 \mathrm{cc}$ を加えて

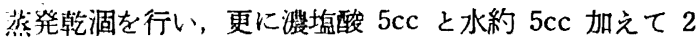
３分間熱した後, $100 \mathrm{cc}$ のメスコルペンに移し, 室温 になるまで放冷してから標線まで水を加之，㴧過したも のを試料液とした(11)。

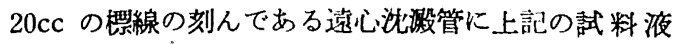
を入れ ( $\mathrm{Mg}$ 餐度 1 3mg 程度が適当)，5\% 安息香酸 2cc. メチールレッド1滴を加え, 更に $1: 4$ アンモ 水を2 3cc 加えてアルカリ性にした後， $1: 4$ 㙁酸浴液 
を加えて液を微紅色（pH 4 5) とし，約 1 時間放置す る。次で䅺線まで水を加えて正確に $20 \mathrm{cc}$ とし細い硝子 棒でよく摫拌してから遠心分離（3000 回転，15 分間） を行い，上澄液 $10 \mathrm{cc}$ をビベットにて同樣の遠心沈㳍管 に採取する、これに饱和苳酸安門 $2 \mathrm{cc}$ を加え $1: 4$ 醋酸 水と $1: 4$ アンモ二ヤ水で $\mathrm{pH} 5$ 附近（先に入れたメチ ールレッドが残つているから設紅色を呈する所）にして 4 時間以上放置する。(この際 $\mathrm{pH} 6.4$ 以上のアルカリ 性になら始上5注意）再び前と同样漂線まで水を加 えて $20 \mathrm{cc}$ とし揊拌した後遠心分離 (3000 回転，15 分 間）を行つてから上澄液 $10 \mathrm{cc}$ をコールベンに採取する。 （沘殿した蕧酸 $\mathrm{Ca}$ を $\mathrm{KMnO}_{4}$ で滴定すれば $\mathrm{Ca}$ 定量を 行い得る) 次に $20 \% \mathrm{KCN} 3 \mathrm{cc}$ を加えてから $1: 4 \mathrm{HCl}$ を加えて $\mathrm{pH}$ を稍酸性にし約 5 分間放置した後, EDTA 溶液 $10 \mathrm{cc}$ を正確に加之, EBT 液数滴, 䌐画液 4 5cc. 水を適宜加えてから $\mathrm{MgCl}_{2}$ で滴定する。

\section{III 回收試 験}

動植物性食品 5 種を選んで本定量法により $\mathrm{Mg}$ の回 収試験を行つた所第 2 表のようになつた。

即ち回収率は $99 \%$ ～101\%。間を動摇しており，この ことから本定量法は \pm 10 。程度の誤差をもつものと考え られる。
第 2 表

\begin{tabular}{|c|c|c|c|}
\hline 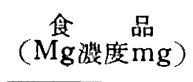 & $\mathrm{Mg}$ 添加量 $(\gamma)$ & 奏测值 $(\mathrm{mg})$ & 回収率 (\%) \\
\hline 大 $(0.967)$ 可 & 500 & $\begin{array}{l}1.460 \\
1.460 \\
1.453\end{array}$ & 99 \\
\hline $\begin{array}{l}\text { H } \\
(1.250)\end{array}$ & 500 & $\begin{array}{l}1.736 \\
1.750 \\
1.733\end{array}$ & 99 \\
\hline$(0.980)$ & 500 & $\begin{array}{l}1.482 \\
1.475 \\
1.475\end{array}$ & 100 \\
\hline${ }^{\text {白 }} \begin{array}{r}\text { 米 } \\
(0.695)\end{array}$ & 500 & $\begin{array}{l}1.181 \\
1.183 \\
1.189\end{array}$ & 99 \\
\hline $\begin{array}{c}\text { ほ5扎ん草 } \\
(1.137)\end{array}$ & 500 & $\begin{array}{r}1.655 \\
1.651 \\
1.620\end{array}$ & 101 \\
\hline
\end{tabular}

IV 食品中の $\mathrm{Mg}$ 含有量

以上述べた方法によつて主要食品 27 種の $\mathrm{Mg}$ 含有量 を定量し，当教室高野等は2が同一標本について Oxin 法

第 3 表 各定量法による食品中 $\mathrm{Mg}$ 量の比較

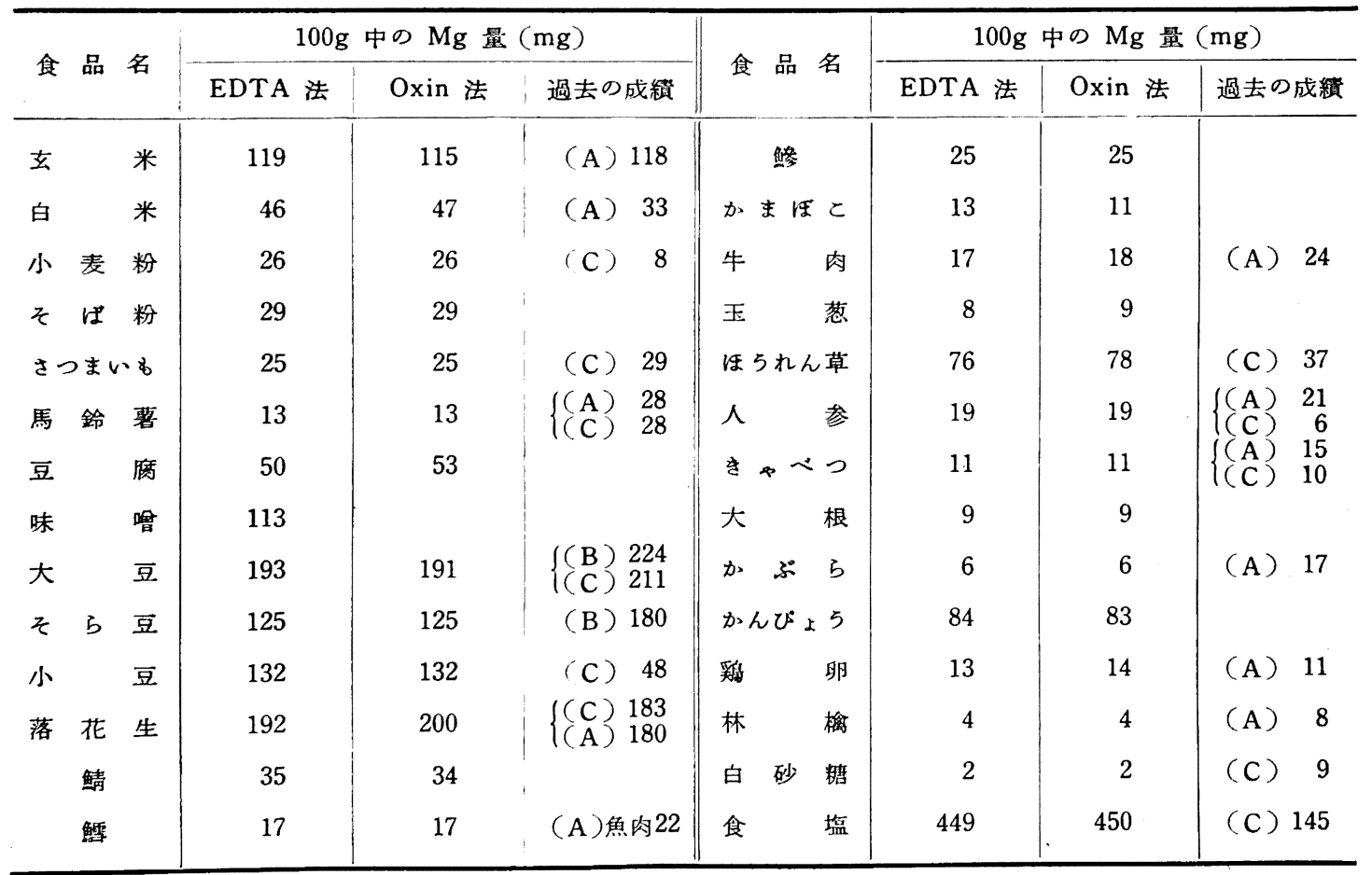

注 $(\mathrm{A}) \cdots \cdots$ (13) 交献引用 $(\mathrm{B}) \cdots \cdots(14)$ 文献引用 $(\mathrm{C}) \cdots \cdots(6)$ 交莶引用 
により分析した結果，及びこれまでに各交献(6)(13)(14)に 記载された成績と比較して見た。その結果は第 3 表の通 クであるが, EDTA 改变法と Oxin 法との比較では数 種類が 3 4\%の差を示したはかは殆どその值が一致し た。從来の成績との比較ではほぼ同様の值を得たものが 多かつたか，白砂糖，食㙁，小麦粉，小豆等相当に差を 生じたすのるあつた。白砂糖及び食塩については試料の 種類の迕いによつて $\mathrm{Mg}$ 含有盟に大きい盖のある性質 のものであるから何ともいえないか，その他のものにつ いては定量方法の相違か影锌していると考えられる。

\section{Vむすび}

Willson (3) は植物組穖内の $\mathrm{Ca}, \mathrm{Mg}$ を定量するために 行われたEDTA に関する種々の研究を報告した中で， $\mathrm{Mg}$ の分析值についてはオキシン法と $15 \%$ 以内の䛤差

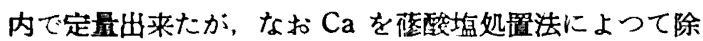
いた後に $\mathrm{Mg}$ の定量を行えば更に一致した結果を得る であろらといつておる。

我々の方法はこの方法に更に安息香酸を用いて Al, $\mathrm{Fe}$ を除去して定量したものであり，Oxin 法との比較 では全く一致したものが多かつた。

この場合に何故 AOAC による重量法と比較しなかつ たかといえば，ビロ矮酸マグネシウムとして測定する重 量法は，食品中に Mn 含有貫の多いときは別に Mn を 定量しなくてはならぬこと，理論的に精度はよくとも操 作に当り熟練を要すること，試料を非常に多量用いなく ては正確に科れはこと等の点から必ずしも拠り所となら ぬと考えたためである。
要するに迅速に行える $\mathrm{Mg}$ 定量法として EDTA 法 は優れた方法といらことができ，正確度す垁用的には充 分であると思 5。唯我々の改変法に於て安息香酸による

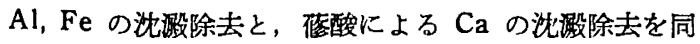
時に行えるよ5にすれば操作は簡略化されるので今後研 究したい所である。

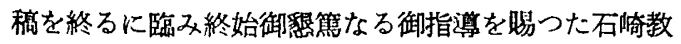
授に満腔の謝意を表します。

\section{参考 文 献}

1. 览玉等 規伴食品分析散定報告 昭 27

2. Schwarzenbach and Ackermann: Helv. Chim. Acta, 31, 1029, 1948

3. A. E. Willson: Anal. Chem. 22, 1571, 1950

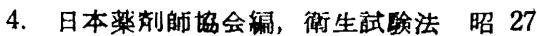

5. Diehl, Goetz Hach: J. Am. Waterworks Assoc 42, 401950

6. 楖沢文正 新渴医学会雑誌 第 67 年下 1062 昭 28

7. 瑞見穞等 品化学 10 昭 23

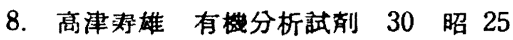

9. 藤巻良知等 栄䓹化学 53 昭 16

10. Chemical Times 5 66 71 昭 26

11. 永原太郎 食䊓分析 108 昭 23

12. 高野晃一等 印刷中

13. 桜井芳人 栄萎化学 229 昭 26

14. Mc Collum, E. V., 栄楼新説 (訳) 2021941

（金沢大学医学部公衆衛生）

\section{女子大学生の垔雓代的}

13 人の自由食をとつている女子大学生について，互

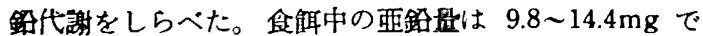
あつて，尿中への排泄量は，0.6〜 $1.8 \mathrm{mg}$ ，基便中へは 3.2 〜 7.9mg であり，提取された归鉛の $8 \%$ か尿中へ， $42 \%$ は筫便中に排泄された。全例とも陽性の亜鉻平衡を示
し，一日平均 $6.6 \mathrm{mg}$ が体内に蓄程された。

Zinc Metabolism of young College women on selfselected diets. H. M. Tribble and F. I. Scoular. J. Nutr. 52; 209 (1954). （野 崎）

\section{嫞人のリボフラヒン代楽}

リボフラビン $\left(\mathrm{B}_{2}\right)$ 代即を 7 人の成人女子についてし らべた。食铒は調節され， $\mathrm{B}_{1} 600 \gamma 300 \mu \mathrm{g} / 1000 \mathrm{Cal} \mathrm{B}$ $1.2 \mathrm{mg}$ でその他の栄往素は National Research Coun. cilの所要量を充していた。血消空腹時全 $\mathrm{B}_{2}$ は平均 3.21 $\mu \mathrm{g} \%$ ，遊離 $\mathrm{B}_{2}(+\mathrm{FMN})$ は $1.41 \mu \mathrm{g} \%$ で，24 時間尿 中排泄量は 315 467 $\mu \mathrm{g}$ で掑取量の $27 \sim 40 \%$ であつた。 $\mathrm{B}_{2} 2 \mathrm{mg}$ 経口負荷では，血清 $\mathrm{B}_{2}$ は 30 分 1 時間で最 高, 5 時間で空腹時の值をとるが，尿中排泄量の最高は
1 時間後で 5 時間後に空腹時 1 時間尿中 $\mathrm{B}_{2}$ 量と同じと なつた。尿中クレアチニン $\mathrm{g}$ 当り $\mathrm{B}_{2} \mu \mathrm{g}$ 量でみると 7 人中 2 人は $\mathrm{B}_{2}$ 椇取䭪旧 $1.2 \mathrm{mg}$ では不適当 $\left(\mathrm{B}_{2} 200 \mu \mathrm{g} /\right.$ クレアチニン $\mathrm{g}$ ，以下）であつた。佔血清と尿との $\mathrm{B}_{2}$ と の間には関係を認めなかつた。

Riboflavin Metabolism of women on controlled diets Mei-Ling Wu, E. Warren and C. A. Storvick. J. Nutr 51, 231, (1953). （野 㱦） 